\title{
Splenic Infarction in a White Boy with Sickle Cell Trait
}

\begin{tabular}{|c|c|}
\hline M. & Callís \\
\hline J.J. & Petit \\
\hline C. & Jordan \\
\hline J.L. & Vives-Corrons \\
\hline C. & Ferrán \\
\hline
\end{tabular}

M. Callís, J.J. Petit, C. Jordan, J.L. Vives-Corrons, C. Ferrán, C.S. de la S.S. 'Principes de España', Servicio de Hematología, Sección de Clínica, Hospitalet de Llobregat, Barcelona (Spain)

To the Editor,

A case of high altitude splenic infarction is presented. The event was precipitated by a sudden change of altitude from 2,356 to $3,555 \mathrm{~m}$. The patient is a hemoglobin S carrier, and this is the tient was found to be a $\mathrm{Hb} \mathrm{S}$ carrier, being the third reported case of high altitude splenic infarct in a white person with sickle cell trait (SCT) $[1,2]$.

A 13-year-old Caucasian boy of southwestern Spain origin was admitted to our Hospital for diagnostic evaluation of splenomegaly. 1 week prior to admission, during the family holidays on the Canary Islands and while ascending the Teide Volcano by cable-car, he complained of acute left upper quadrant pain so he was not able to continue the trip to the summit when he left the cable-car. The boy was seen in a local hospital and, since surgical condition was ruled out, was discharged with the diagnosis of mountain sickness. On arriving back home, the parents brought the boy to our hospital because of persistence of pain. Physical examination only revealed splenomegaly of $3 \mathrm{~cm}$ below the left costal margin. Routine laboratory work-up showed LDH levels of 1,430 $\mathrm{mU} / \mathrm{ml}$ with a isoenzyme profile of 1:22.4\%, 11:23.6\%, IП:21.80/o, IV:15.4\%, and V:16.8\% (normal values 1:26.5\%, 11:4.0\%, 111:20.5\%, IV:7.5\%, and V:11.5\%). A spleen scan showed splenomegaly with a large defect in the lower central portion. Celiac arteriography revealed mixed images with filling defects and contrast's blotches. A latex-echinococcus test was negative. Blood smear showed slight anisocytosis and some target cells. The sickling test showed to be positive after $3 \mathrm{~h}$

incubation on NaMBS. Starch block ( $\mathrm{pH}$ 8.6) and agar citrate ( $\mathrm{pH}$ 6.2) electrophoresis demonstrated a hemoglobin AS pattern. Globin chains were separated showing alpha A, beta A, and beta $\mathrm{S}$ chains. $\mathrm{Hb} \mathrm{A} 2$ was lower than $2 \%$ and $\mathrm{Hb} F$ was $3.8 \%$. A family study revealed SCT in the mother and a 26-year-old brother. The boy is well $3 \mathrm{~V} 2$ years after the event.

We want to point out the clinical benignity of SCT in this family, which has needed extreme atmospheric conditions to precipitate sickling when changing from an altitude of 2,356 $\mathrm{m}$ (basis of the cable-car) to $3,555 \mathrm{~m}$ (top of the same) in $8 \mathrm{~min}$ (duration of the trajection).

References

Rywlin, A.M.; Benson, J.: Massive necrosis of the spleen, with formation of a pseudocyst. Report of a case in a white man with sickle cell trait. Am. J. clin. Path. 36: 142 (1961). O’Brien, R.T.; Pearson, H.A.; Godley, J.A.: Spencer, R.P.: Splenic infarct and sickle (cell) trait. New Engl. J. Med. 287: 720 (1972). 
